\title{
Digital Reproducibility and the Culture Industry: Popular Music and the Adorno- Benjamin Debate
}

\author{
Ryan Moore
}

\section{Introduction}

The correspondence between Theodor W. Adorno and Walter Benjamin - two central figures in the development of critical theory associated with the Frankfurt School - has been called "one of the most significant documents in the history of neo-Marxist literature" (Buck-Morss 1977: 139).[1] Adorno and Benjamin shared an instant intellectual kinship, and throughout his life Adorno was greatly influenced by Benjamin's method for tracing fragmentary elements into constellations of interconnected relationships (Jameson 1990; Jay 1984). But their correspondence also revealed significant disagreements, especially in an exchange of letters that expressed Adorno's negative responses Benjamin's essays on art, Kafka, Baudelaire and nineteenth century Paris (Adorno et al. 2007: 100-41).[2] A "debate" or "dispute" between Benjamin and Adorno has since been identified about everything from aesthetics and mass culture to dialectics and Disney (Arato and Gebhardt 1982; Buck-Morss 1977; Hansen 1993; Lunn 1982; Rosen 2004; Wolin 1982).

The ideas of Benjamin and Adorno occupy an increasingly central position in the academic fields of art, literature, media studies, musicology and philosophy (Benjamin 2005; Ferris 2004; Gibson and Rubin 2002; Gumbrecht and Marrinan 2003; Hansen 2011; Hanssen 2006; Hanssen and Benjamin 2002; Huhn 2004; Middleton 2006; Subotnik 1996). However, in another example of how the discipline's mainstream has failed to incorporate the insights of critical theory and cultural studies (Agger 2007), Benjamin and Adorno have made a smaller impact on sociology - including the sociology of culture and media sociology - although there have been important exceptions on the margins of the discipline (DeNora 2003; Witkin 2003). My argument is that Adorno and Benjamin's conflicting exchange over mass culture and technological reproducibility has extraordinary sociological implications for understanding contemporary media and the contradictions embedded within them. My specific focus will be the music industry and the consequences of digital technologies for the production, exchange, and consumption of music.

While the debate between Adorno and Benjamin spans a wide range of aesthetic, philosophical and political issues, I will focus on their divergent appraisals of the emergent mass culture or "culture industry" (Bronner 2002; Held 1980; Jay 1973; Kellner 1989). Influenced by the playwright Bertolt Brecht, Benjamin maintained that technologies of reproduction were closing the distance that traditionally separates people from culture while also enabling audiences to become involved as participants and producers. Adorno rebuked Benjamin for these optimistic assessments and countered by further developing his critique of popular music, arguing that standardization was an inevitable product of the commodification of music and that all forms of mass culture effectively pacified their viewing or listening audience; his aesthetic and political loyalties remained with the "serious" forms of music he sharply distinguished from popular music. Benjamin, on the other hand, sensed that the capitalist production of culture was inherently contradictory, as he supposed that media technologies based on reproducibility would allow people to appropriate, de-contextualize and re-contextualize cultural forms in ways that had initially been undertaken by the avant-garde. 


\section{The Forces and Relations of Production in Digital Media}

I suggest that the debate between Adorno and Benjamin be reframed in Karl Marx's terms as a contradiction between the productive forces and the social relations of production. For Marx (1978), productive forces include all that give people the power to appropriate and transform nature through labor, especially technology and advancements in the labor process, while the relations of production refer to the ownership of these productive forces, the social organization of productions, and the relationships between classes. He theorized that there was a fundamental, internal contradiction in capitalism between the relations and forces of production, particularly because capitalists depend on technological innovation in competing with one another to maximize profit, and yet this technological dynamism also systemically creates periods of crisis and tends to undermine profitability in the long run.[3]

In their debate over mass culture, Benjamin tended to focus on the technical dimensions of reproducibility through media, while Adorno was more concerned with the relations of domination and control embedded in the culture industry. My argument is that the debate between the two theorists expresses an ongoing contradiction within the media and culture industry, a contradiction that has become more intense in the contemporary digital age. The point here is not to issue a verdict in the debate between Adorno and Benjamin, but rather to understand the debate between them as representing two sides of an ongoing dialectical contradiction. Since the mid-20th Century when Adorno and Benjamin were debating the consequences of emerging forms of mass media, the contradictions they identified have accelerated and intensified. On the one hand, the digitalization of media has multiplied the possibilities of reproducibility, threatened the system of private ownership through copyright and further eroded the distinctions between production and consumption among audiences. Meanwhile, the means of cultural production have been increasingly centralized in the hands of a small number of multinational firms, with these firms developing into conglomerates whose holdings across multiple forms of media have facilitated the further commercialization of culture.

In sum, while the productive forces of digital media create possibilities for socialization and democratization, the social relations of the global media conglomerates tend toward further privatization and centralization. My argument thus intersects with the one recently made by Christian Fuchs (2011) with regard to Google. Utilizing the same concepts of relations and forces of production from Marx, Fuchs writes:

At the level of the technological productive forces, we see that Google advances socialization, the co-operative and common character of the online-productive forces: Google tools are available for free, Google Documents allows the collaborative creation of documents; GMail, Blogger, and Buzz enable social networking and communication, YouTube supports sharing videos, Google Scholar and Google Books help better access worldwide academic knowledge, etc. These are all applications that can give great benefits to humans.

This statement is especially applicable to the consequences of digitalization for music. These same productive forces have made it easier and cheaper for people create and exchange music, especially digital technologies that have enabled the free online exchange of music in spite of the recording industry's efforts to maintain private ownership. Here we confront the central contradiction between the development of digital productive forces and the capitalist social relations based on centralized corporate ownership. Fuchs summarizes the other side of this contradiction embedded in digital capitalism:

But at the level of the relations of production, Google is a profit-oriented, advertising-financed moneymaking machine that turns users and their data into a commodity. And the result is large-scale surveillance and the immanent undermining of liberal democracy's intrinsic privacy value. Liberal democratic values thereby constitute their own limit and immanent critique.

\section{Benjamin on Technological Reproducibility}

Writing his now famous artwork essay [4] in 1936, Benjamin sought to understand the consequences of emerging media technologies for art and culture. In more traditional societies, authenticity and an "aura" had resided in the artwork's uniqueness and singularity in time and space. In modern society, technologies that facilitate the reproduction of images and text cause the erosion of this aura based on singularity, originality and authenticity. Benjamin (2008: 20) acknowledged that "the work of art has always been reproducible" through imitations and replicas, yet 
maintained that "the technological reproduction of artworks is something new." The woodcut allowed graphic art to be mechanically reproduced for the first time during the Middle Ages, followed by printing and the reproduction of writing. The next stage evolved during the nineteenth century, first with the introduction of lithography, then with the advent of photography, and finally with the reproduction of sound at the end of the century. A reproducible work of art is dislodged from tradition and authenticity, thus dispelling the aura that derives from a unique presence in time and space. As Benjamin (2008: 22) put it:

[W] hat withers in the age of technical reproducibility of the work of art is the latter's aura...It might be stated as a general formula that the technology of reproduction detaches the reproduced object from the sphere of tradition. By replicating the work many times over, it substitutes a mass existence for a unique existence.

Benjamin expressed deep ambivalence about the erosion of aura when writing about Baudelaire (2006), and also in his essay on storytelling (1968), but in the artwork essay he welcomes it as nothing less than a revolutionary development. He begins by paraphrasing Marx's prophecy that capital would eventually create "conditions which would make it possible for capitalism to abolish itself" (Benjamin 2008: 19). Aura and authenticity had been connected to what Benjamin (2008: 24) called the "ritual function" of art, whereby the artwork was endowed with a kind of magical or religious power that conferred a sense of distance from its audience. This sacredness endured even once art was secularized, finding expression in Romanticism's call for l'art pour l'art (art for art's sake), but he also found that the Italian Futurists were creating a fascist form of aura with an aesthetic of political violence and war. In contrast, Benjamin hoped that reproducible media like film could close the distance from its audience and thereby facilitate a kind of critical scrutiny that is unthinkable when art is the revered object of ritual. In an oftquoted passage, Benjamin (2008: 25) imagined that a new revolutionary culture was being born:

[A]s soon as the criterion of authenticity ceases to be applied to artistic production, the whole social function of art is revolutionized. Instead of being founded on ritual, it is based on a different practice: politics.

Benjamin maintained that a more participatory culture in which audiences took a critical approach would replace the contemplative stance of individuals absorbed by sacred artworks. He cited daily newspapers as one example:

For centuries it was in the nature of literature that a small number of writers confronted many thousands of readers. But this began to change toward the end of the past century...It began with the space set aside for 'letters to the editor' in the daily press. (Benjamin 2008: 33)

In this more participatory culture, "the distinction between author and public is about to lose its axiomatic character" (Benjamin 2008: 33-34). The model for Benjamin's vision of the merger between production and consumption in the age of technological reproducibility was provided by Bertolt Brecht's epic theatre, which sought to shock the audience by disrupting its taken-for-granted assumptions and involving them as collaborators in the performance. Benjamin's other key source of inspiration was the technique of montage practiced by French symbolists, Dadaism and the Surrealists, and Soviet constructivists. As reproducibility liberates objects and images from their original context of time and space, it becomes possible to recombine and juxtapose the leftover cultural fragments in ways that create new meanings while destroying traditional ones. Media technologies enable techniques of montage to spread beyond the art world:

It has always been one of the primary tasks of art to create a demand whose full satisfaction has not yet come... Dadaism attempted to produce with the means of painting (or literature) the effects which the public today seeks in film. (Benjamin 2008: 38)

Benjamin (1978) had introduced his argument for the socialization of the means of cultural production in his 1934 address at the Institute for the Study of Fascism in Paris, titled "The Author as Producer." Focusing on literature, he began with the issue of "political tendency" in writing and emphasized the form of literary production over its content because "the bourgeois apparatus of production and publication can assimilate astonishing quantities of revolutionary themes, indeed, can propagate them without calling its own existence, and the existence of the class that owns it, seriously into question" (Benjamin 1978: 229). Revolutionary intellectuals - Benjamin specifically refers to writers and photographers - are in danger of having their work co-opted by the capitalist media, and therefore they must struggle to socialize the apparatus of production and break down its specialized division of labor. Here again, he refers to the example of Brecht's epic theatre: 
What matters, therefore, is the exemplary character of production, which is able first to induce other producers to produce, and second to put an improved apparatus at their disposal. And this apparatus is better the more consumers it is able to turn into producers - that is, readers or spectators into collaborators. (Benjamin 1978: 233)

\section{Adorno on the Culture Industry}

In a letter written to Benjamin in 1936, T.W. Adorno referred to the artwork essay as an "extraordinary study" but objected to "certain Brechtian motifs" he found there (Adorno et al. 2007: 120-21). Adorno accused Benjamin of harboring "the anarchistic romanticism of blind confidence in the spontaneous power of the proletariat in the historical process" (Adorno et al. 2007: 123). By this time he had begun to develop his notorious denunciations of popular music. In an essay published in 1932, "On the Social Situation of Music," Adorno (2002a: 425) disparaged "light music" because "as pure commodity, it is the most alien of all music to society; it no longer expresses anything of social misery and contradiction, but forms rather in itself one single contradiction to this society." In his letter to Benjamin, Adorno discussed his impending completion of an essay that summed up his infamous criticisms of jazz: "It arrives at a complete verdict on jazz, in particular by revealing its "progressive" elements (semblance of montage, collective work, primacy of reproduction over production) as facades of something that is in truth quite reactionary" (Adorno et al. 2007: 125).

Adorno then responded to Benjamin directly with a critique of popular music titled "On the Fetish Character in Music and the Regression of Listening," published in 1938 after he had taken refuge in the United States from Nazi Germany. Here Adorno (2002b: 289) lamented the standardization of music resulting from its transformation into a commodity form: "everything is so completely identical that preference in fact depends merely on biographic details or on the situation in which things are heard." In the essay "On Popular Music," published in 1941, Adorno identified the problem with popular music as one of standardization, by which he meant that songs sounded the same but also that the individual parts within a song were interchangeable with each other. He thus focused on the capitalist imperatives to minimize the costs of production and eliminate risk, which in the realm of popular music meant that songs would be formulaically duplicated if they became commercial hits:

As one particular song scored a great success, hundreds of others sprang up imitating the successful one. The most successful hits, types, and 'ratios' between elements were imitated, and the process culminated in the crystallization of standards. Under centralized conditions such as exist today, these standards have become 'frozen'.(Adorno 2002c: 443)

Adorno's view was that the oligarchy of the recording industry was responsible for the generic quality of popular music:

Large-scale economic concentration institutionalized the standardization, and made it imperative. As a result, innovations by rugged individualists have been outlawed. The standard patterns have become invested with the immunity of bigness'the King can do no wrong.' (Adorno 2002c: 443)

While economic concentration and the desire to minimize risk and production costs leads to formulaic types of popular music, Adorno believed that this standardization must be disguised, for otherwise there would be resentment from mass audiences. The music industry needs to maintain the illusion that its star performers have become successful on the basis of their own merits and that consumers have freely chosen to enjoy the songs that have been marketed to them. Adorno (2002c: 445) referred to this as "pseudo-individualization," which he defined as "endowing cultural mass production with the halo of free choice or open market on the basis of standardization itself." Pseudo-individualization could certainly be found in the creation of celebrity, but Adorno also heard it at work within individual songs, where superficial differences such as a song's "hook" and even the improvisational moments in jazz served to conceal the systematic standardization of popular music. Once the balance between standardization and pseudo-individualization is achieved, the process of advertising and promotion that Adorno called "plugging" is used to saturate the public with hype. This plugging is facilitated by the culture industry's control over the various organs of the media:

Provided the material fulfills certain minimum requirements, any given song can be plugged and made a success, if there is adequate tie-up [sic] between publishing houses, name bands, radio and moving pictures'. (Adorno 2002: 447) 
Adorno's condemnation of popular music shares some affinities with that of conservative critics of mass culture like Matthew Arnold. Adorno has been widely criticized for his elitism and what some have seen as his racist judgments about popular music, particularly his attacks on jazz (Huyssen 1983; Gendron 1986; Gracyk 1992; Wilcock 1996; Witkin 2000; see also Paddison 1982). But unlike Arnold, who feared that mass culture would lead to cultural and political anarchy, Adorno believed that the commodification of culture and music would facilitate what he called "social cement" to refer to conformity and the reproduction of capitalism by pacifying mass audiences. The only signs of resistance he could find were among those listeners, presumably like himself, who rejected popular music altogether:

To dislike the song is no longer an expression of subjective taste but rather a rebellion against the wisdom of a public utility and a disagreement with the millions of people who are assumed to support what the agencies are giving them. Resistance is regarded as the mark of bad citizenship, as inability to have fun, as highbrow insincerity, for what normal person can set himself against such normal music? (Adorno 2002c: 464)

Nevertheless, Adorno never articulated why some listeners could resist the onslaught of popular music or how such refusals might translate into political action.

\section{Reproducibility, The Recording Industry, and Popular Music}

The dispute between Adorno and Benjamin arose less from an intrinsic incompatibility between their views than from their radically different points of departure, with Adorno singling out the commodified relations of the culture industry as Benjamin considered the consequences of new media. I will examine three dimensions of popular music that have developed historically through conflicts between the centralizing and standardizing processes of the culture industry and the democratizing consequences of technologies that effectively socialize the ownership of music. Table 1 is intended to be a guide for how the argument will unfold as I consider the historical conflicts that have shaped the field of popular music.

Examining the relations between capital and reproducible technologies in the recording industry, we first discover that the crisis of the digital age represents the most intense manifestation of an enduring history of conflict, for new technologies are just as often a threat as a boon to the profits and private ownership of the major labels. Next, we examine how these divergent forces have created a bifurcated field in which the hybrid forms of music created by a growing number of musicians on the margins of the industry contrasts with the major labels' increasing focus on a releasing a restricted number of standardized products geared toward short-term profit. Finally, the divergent perspectives represented by Adorno and Benjamin illuminate two ongoing forms of struggle among musicians, one in subcultures that try to remain independent from the major labels and mainstream audiences, the other among musical producers who blur the boundaries between production and consumption in ways that challenge private ownership.

Table 1. Capital, Technology, and Popular Music

\begin{tabular}{|l|l|l|}
\hline & $\begin{array}{l}\text { The Culture Industry, Relations of Production } \\
\text { (Adorno) }\end{array}$ & $\begin{array}{l}\text { Technological } \\
\text { Reproducibility, Forces of Production } \\
\text { (Benjamin) }\end{array}$ \\
\hline $\begin{array}{l}\text { Capital and technology in the } \\
\text { recording industry }\end{array}$ & $\begin{array}{l}\text { Centralization of capital; absorption of } \\
\text { companies into conglomerates spanning } \\
\text { multiple forms of media. }\end{array}$ & $\begin{array}{l}\text { New media increase profit (7-inch and } \\
\text { 12-inch vinyl, CDs) but also the threat of } \\
\text { piracy (DAT, MP3) }\end{array}$ \\
\hline The production of music & $\begin{array}{l}\text { From centralized standardization (40-50s) to } \\
\text { an "open system" (60s-90s) to conglomerate } \\
\text { contraction }\end{array}$ & $\begin{array}{l}\text { Access to technology enables greater } \\
\text { participation in music scenes; } \\
\text { production and consumption merge. }\end{array}$ \\
\hline $\begin{array}{l}\text { Resistance and social struggles over } \\
\text { music }\end{array}$ & $\begin{array}{l}\text { Anti-corporate forms of independent music; } \\
\text { aesthetic of authenticity opposed to main- } \\
\text { stream music. }\end{array}$ & $\begin{array}{l}\text { Sampling and remix in hip hop and } \\
\text { mash-ups; legal conflicts over private vs. } \\
\text { common ownership of music }\end{array}$ \\
\hline
\end{tabular}




\section{Capital and Technology in the Recording Industry}

An examination of the political economy of media today reveals a continuing process of what Marx (1977: 777) identified as the "centralization of capital," for the vast majority of the media and entertainment produced for world consumption is owned by a shrinking number of multinational conglomerates (Bagdikian 2004; Croteau and Hoynes 2006; McChesney 1999). These larger processes of economic transformation have made a significant impact on all aspects of the music industry: record labels, radio, retail, and live performance. The recording industry, following a torrent of mergers and acquisitions, is presently dominated by the 'Big Four' - Universal, Sony, Warner and EMI that sell over 80 percent of the music in the U.S. and over 70 percent worldwide.

The problems posed by digital reproducibility have affected all the media industries in various ways, but within the recording industry the crisis is especially pronounced and seemingly intractable. The illegal exchange of free music has continued to increase with the use of more decentralized servers that allow people to share and download MP3 files, despite the industry's successful lawsuits against Napster and other peer-to-peer online services. The recording industry has undertaken several attempts to stop what it calls "internet piracy," including some highly publicized lawsuits against file-sharing consumers, but these have not only been ineffective but further antagonized musicians and consumers. In the U.S., sales from recorded music have fallen by more than half from their peak level of $\$ 14.6$ billion in 1999 , at the dawn of the MP3 and Napster, to $\$ 6.9$ billion in 2010 .

The contradictions between technological reproducibility and the culture industry have reached new extremes in the digital era, but the history of popular music is rife with instances in which new technologies have both endangered and enriched the industry at different times. During the years that Adorno was developing his critique of the culture industry, recorded music in the United States was indeed the standardized product of an oligarchy in which a small number of firms and powerful interests dominated. In 1948, American radio broadcasting consisted of four national networks and their local affiliates, and four companies accounted for 81 percent of all the top-ten hit records (Peterson and Berger 1975: 160). However, during the first half of the twentieth century, recordings were not the primary commodities of the music industry, which was still based on live performance, songwriting and publishing, and selling sheet music. Sound had been recordable and reproducible since the nineteenth century, but records and phonographs were still too unwieldy and expensive for mass consumption.

Musical recordings began to increase in importance after World War II, as Columbia developed the 12 inch, 33 $1 / 3 \mathrm{rpm}$ vinyl record and RCA followed with the $7 \mathrm{inch}, 45 \mathrm{rpm}$ single. The major labels invested in the research to develop a more accessible medium for recorded music, but their unintended effect was to give the smaller, independent labels a chance to compete in the market for commercial pop, thereby decentralizing the industry. One key advantage of the $7 \mathrm{inch}, 45 \mathrm{rpm}$ record - the standard format for pop music until the mid-1960s - was that it was much less breakable than its larger counterparts, and therefore could be packaged, shipped, and distributed in mass quantities. Meanwhile, the number of local radio stations multiplied as the Federal Communications Commission (FCC) granted a backlog of licenses after the war, when the networks had their sights on the emerging medium of television. These smaller, independent stations were unable to provide the variety of programming offered by the networks, and so much of their airtime was devoted to playing records. This gave the independent record labels, particularly those specializing in rhythm and blues or country music, an unprecedented opportunity to get their music on the air at the growing number of stations that catered to specific tastes or regional styles (Gillett 1983; Peterson 1990).

The recording industry would be significantly decentralized by the end of the 1950s: whereas the largest four record companies had over 80 percent of the market for hit singles through the 1940s and still maintained 74 percent as late as 1955, by 1959 their portion of Top Ten records had declined to just 34 percent (Peterson and Berger 1975: 160). Over the next two decades, the recording industry enjoyed its time of greatest profitability, chiefly by selling rock music to the sizeable baby boom generation. The industry was re-centralized in the process, although now the major labels adopted a new strategy that dispersed creative control to subsidiaries and independently contracted producers (Lopes 1992; Dowd 2004). After a sales slump in the early 1960s, the recording industry reaped massive profits from the Beatles and the other groups associated with the British Invasion, followed by the folk rock and psychedelic groups centered in California, as rock music became the central medium of cultural expression among great numbers of young people. Beginning in the second half of the 1960s, the $331 / 3 \mathrm{rpm} \mathrm{LP}$ - mainly used for jazz, folk, and classical music whereas the $45 \mathrm{rpm}$, 7-inch was used for pop records - became the preferred medium of rock music, and a new format of 'album-oriented rock' emerged on FM radio stations distinguished from the AM stations dedicated to hit singles. 
By 1974, the music business as a whole had become a $\$ 2$ billion industry, which at that time was roughly equal to the revenues generated from professional sports and motion pictures combined (Chapple and Garofalo 1977: xi). The industry was also re-centralized in a flurry of mergers and conglomeration. In 1973, the largest four record companies were, for the first time in two decades, responsible for more than half of all Top Ten records (Peterson and Berger 1975: 160). As rock music became big business, the infrastructure of the industry also expanded to include talent agencies, managers, concert promoters, lawyers, journalists, and magazines like Rolling Stone. In short, by the mid-1970s, while the rest of American industry slumped, popular music had grown into a multi-billion dollar business, the recording industry had been recentralized by a small number of large companies utilizing a decentralized approach to production, and many people had discovered new ways to make money from various aspects of the music and its performance.

Despite their ability to regain control of the market while undergoing extraordinary growth, the recording industry continued to see technologies of reproducibility as a potential threat. The British Phonographic Industry even launched a campaign during the early 1980s using the slogan "Home Taping Is Killing Music." The development of digital technology in the form of the compact disc (CD) was initially the catalyst to a major period of growth from 1983-84 until the industry's peak sales year of 1999. Compact discs did not yet have the capacity to be recordable or rewritable, so the recording industry profited handsomely as consumers replaced their old record collections with compact discs and repackaged box sets. In the meantime, the recording industry squashed the development of the Digital Audio Tape (DAT) that would have allowed consumers to make perfect reproductions of music recorded from a CD. As Sony was poised to introduce their newest invention, the other major labels insisted that Sony manufacture DAT with copy protection technology in place or else they would refuse to license their label's music (Knopper 2009).

Although Digital Audio Tape was squashed, advances in digital technology still made it possible to copy data from personal computers to recordable CDs. The most threatening form of reproducibility to confront the recording industry has proven to be the compression of audio content into an MP3 file. People began exchanging MP3 files through the internet in the late 1990s, with Napster eventually emerging as the most popular site for the free exchange of music. Napster would be sued, first by the Recording Industry Association of America (RIAA), then by the band Metallica and the rapper Dr. Dre in 2000, and found guilty of violating the recently passed US Digital Millennium Copyright Act. Meanwhile, the RIAA also launched a highly publicized campaign of lawsuits against thousands of individual consumers who were sued for $\$ 750$ per illegally downloaded song. Napster was effectively shut down by the recording industry, but the free exchange of music has continued online with new sites that were developed utilizing more decentralized methods of file sharing.

The RIAA estimates that only about one-third of the music acquired by U.S. consumers in 2009 was paid for, and while the extent of online piracy is impossible to know with any certainty, it claims that American internet users download somewhere between $\$ 7$ billion and $\$ 20$ billion worth of digitally pirated music every year (http://www. riaa.com/physicalpiracy.php?content_selector=piracy-online-scope-of-the-problem). A key reason for the industry's woes is the public's low regard for the music business. The highly publicized Napster case created a backlash against the major labels and the wealthy musicians who filed suit, and the RIAA suits against consumers - for example, a 12 year old living in a public housing project named Brianna LaHara made the cover of the New York Post in 2003 after the RIAA sued her mother, eventually settling out of court for $\$ 2,000$ - only served to further increase the public animosity. The RIAA's anti-piracy campaign appeals to the notion that consumers "support the artist" when they legally purchase their music, but the exploitation of musicians by record companies is well known (see Albini 1997). As one industry insider summed it up, "The average kid thinks, I'm not stealing from the bands; I'm stealing from the record companies, and the bands say the record companies steal from them already. They could care less" (Sheff and Tennenbaum 2007: 342). Established artists like Prince, Nine Inch Nails, and Radiohead have released musical recordings independently of any record company by simply allowing them to be downloaded from their websites. Radiohead took an innovative step with the release of In Rainbows in 2007 in the form of an "electronic tip jar" that allowed people downloading the album to decide how much or how little they wanted to pay for it. In bypassing record companies altogether, the members of Radiohead claim that they made more money from In Rainbows than all their other best-selling albums combined (Kot 2009: 236).

\section{The Production of Music}

The dialectic between centralization and reproducibility constructs a field of popular music that is shaped 
something like a pyramid, with standardization at the highest levels of the industry's mass marketed pop in contrast to diversification and hybridization in the lower regions where music is created within local scenes or specialized niche genres. As Adorno foresaw, the most commercially successful and popular forms of music have tended toward standardization because the recording industry, like the culture industry as a whole, seeks to maximize profit and minimize risk. In the years prior to rock \& roll's breakthrough in 1955-56, the centralized dominance of the recording industry by an oligopoly of four companies resulted in relatively homogenous forms of popular music: most of the hit records were performed by established or fading stars, hit records tended to stay at the top of the charts for longer periods of time, and a larger numbers of hits were cover versions of previously recorded songs (Peterson and Berger 1975: 161). The majors were initially antagonistic in their response to rock \& roll as it emerged in 1955-56, largely because of the controversy surrounding the music's sexual connotations and association with black culture, but also because many within the industry dismissed it was a passing fad. The major labels purchased the contracts of some of the most successful white musicians, or in other instances paid socially acceptable artists to record compromised and sanitized versions of songs that had been originally performed by rock \& roll musicians.

The music industry's greatest period of accumulation spanned from the mid-1960s through the late 1970s - in terms of musical trends, from Beatlemania through the last days of disco. Especially in the early years of 1967-68, relations between countercultural musicians and representatives from the recording industry revealed deep conflicts of cultural ideals about music and commerce. For example, in late 1967 an executive at Warner Bros. Records dashed off an enraged letter to the management of the Grateful Dead as the band was recording its experimental sophomore album, Anthem of the Sun: "this is the most unreasonable project with which we have ever involved ourselves... You are now branded as the most undesirable group in almost every recording studio in Los Angeles" (http:// www.lettersofnote.com/2011/02/grateful-dead-has-many-problems.html). Before long, however, the majors would discover that they could capitalize on the burgeoning youth culture more effectively if they utilized semi-autonomous subsidiary labels run by younger people with a more organic connection to the music. By the 1970s, rock had become the highest selling form of popular music for an expanding market of baby boomers, and the music had splintered into more specialized genres (country rock, heavy metal, singer-songwriters, southern rock, progressive art rock) that could be marketed to particular taste groups shaped by various social differences. But while the musical spin-offs became more numerous, the sounds and styles of what has been consecrated as "classic rock" solidified during these years into a general standard of musical, visual and discursive elements.

The punk explosion of 1976-77 presented a challenge to the solidifying rock music establishment, exposing and ridiculing its conventions through a negative example of short songs, short hair, and bleak attitudes. Punks attacked mainstream rock music for functioning as what Adorno had called "social cement": relinquishing the voice of dissent it developed during the 1960s, rock music had become complacent, both aesthetically and politically, in the process of attaining commercial success within the culture industry. Much of punk's provocation was generated by the appropriation and juxtaposition of seemingly incongruous signs - from safety pins to swastikas - in ways that Benjamin and Brecht termed a "shock effect" that disorients the naturalized uses and meanings of cultural constructions (Grossberg 1986; Heddige 1979; Marcus 1989; Savage 1993). Punk subculture formed an alternative network of independent media through a "do-it-yourself" (DIY) ethic, which maintained that people should not be content with being consumers and spectators but instead could become active participants in producing a subterranean network of independent labels, college radio stations, and self-published fanzines. Seizing the means of communication to show that anyone could make music or publish a fanzine, punks were trying to demystify what Benjamin might have seen as the "aura" that surrounded rock music once it became a big business characterized by musical virtuosity, spectacular performance and larger-than-life celebrities.

The fusion of production and consumption was also fostered in the practices of sampling and turntable scratching, which were essential elements in the evolution of rap and hip hop from the late 1970s through the 1980s. Both developed initially from DJs who played records at parties, not in the intended manner but instead by isolating the "break beats" in any given song where the rhythm section evolves into an especially funky groove. (Chang 2005; Potter 1995; Rose 1994; Schloss 2004; also see Forman and Neal 2004) The advent of digital samplers, which hip hop producers began utilizing in the second half of the 1980s, enabled the DJ to move beyond the turntables to loop and remix snippets of sound into a recycled musical pastiche. Sampling fulfills Benjamin's prophesy that technological reproducibility would enable montage - the practice in which cultural fragments are appropriated, juxtaposed, and reassembled in ways that create new meanings - to be extended beyond the modernist avant-garde into mass media and mass culture (Goodwin 1988; Schumacher 2004). 
The divergent processes of corporate concentration and digital reproducibility have shaped the music world into a commercial pyramid with standardized pop at the summit and a proliferating number of musical styles and hybrids subsisting in local scenes and cyberspace. Following the mergers of the 1990s, labels began slashing the size of their rosters to focus on a smaller number of more commercially dependable pop acts. The "open system" that developed with the ascendancy of the record industry in the late 1960s and early 1970s began to tighten and narrow through global conglomeration in the late 1990s; a large number of "alternative" performers who had been signed in the early part of the decade were dropped by their labels during this time (Knopper 2009; Kot 2009; Park 2007). As one former music industry executive put it: "Corporations want irrational growth, but the music business has historically worked on long-term artist development. Now there is an incredible lack of patience for developing artists. Where you program for your parent company's immediate gratification, you sign stuff that's easy to digest, not what you consider brilliant" (Sheff and Tannenbaum, 2007: 339). Likewise, after their acquisition of radio stations in every region of the U.S., Clear Channel narrowed its playlists, censored "controversial" performers, and eliminated the diversity of local media in favor of homogenous programming (Klinenberg 2007).

Meanwhile, the opportunities for ordinary people to create, record and distribute music have continued to increase with each new development of technological reproducibility and the exponential growth of independent media outlets. Computer software and digital technologies have made it cheaper and more convenient for musicians to do the work of recording and mixing that once could have only been done in a studio, while the internet provides innumerable outlets for distribution, promotion, and networking with audiences. By 2008, over 5 million bands had created MySpace pages that allow musicians to upload their songs, post tour dates, and communicate with fans (Kot 2009: 213). The increasingly unnecessary role of the major labels was especially evident in 2010, when the group Arcade Fire released The Suburbs, an album that debuted at the number one position on the charts in America, Britain, Canada, and Ireland despite being released on the independent Merge Records from Chapel Hill, North Carolina, a label that has been owned and operated since 1989 by two musicians from the local indie rock scene. Following the release of The Suburbs, Arcade Fire played a concert at Madison Square Garden that sold out in just a few hours and was streamed live to an estimated 1.8 million viewers, and then at the 2011 Grammys they became the first independent recording group to receive the award for Album of the Year, winning out over Eminem, Katy Perry and Lady Gaga.

\section{Resistance and Social Struggles over Music}

Finally, Adorno and Benjamin and their corresponding emphasis on the culture industry and technological reproducibility illuminate two different sources of conflict between musicians and the industry. Adorno's elitist defense of "serious" music and dismissal of the popular is often criticized in the academic world, but his kind of opposition between commercialism and quality music is commonly upheld and espoused within local scenes and subcultures. The DIY network of independent media that have supported various underground scenes since the late 1970s was constructed in opposition to the major labels, which are perceived as a homogenizing and standardizing force in music, driven by the profit motive to exploit their musicians and consumers without regard for the quality of the music (Azerrad 2002; Hesmondhalgh 1997; Moore 2007; Thompson 2004). So-called "indie rock" has developed into a cultural milieu akin to what Pierre Bourdieu $(1993,1996)$ termed a field of cultural production where economic capital and symbolic capital are diametrically opposed, as was the case in the literary world of nineteenth century Paris analyzed by Bourdieu. In the artistic field, symbolic capital accrues for artists who appear disinterested in commercial success by taking an approach of "art for art's sake," while conversely those who take a mercenary approach to artistic production, or those who achieve mass popularity or the consecration of official powers, are symbolically devalued because their art is suspected of compromise. Similarly, in the music field, the commercially successful are often discredited or accused of "selling out," while many less popular musicians have accumulated symbolic capital through their eccentric creations conceived on the margins of the recording industry.

If Adorno's perspective prompts a search for commercial independence and creative autonomy from the culture industry, Benjamin's encourages an investigation of contradictions within the dynamic between media and capital that present opportunities for subversion. Discarding the fetish for originality, Benjamin directs our attention to the social conflicts facilitated by reproducibility, suggesting that digitalization facilitates the erosion of distinctions between production and consumption in the development of a participatory culture. In short, if Adorno's critique anticipates the anti-corporate aesthetic of indie rock, then Benjamin's summons the DJ engaged in sampling and remixing within contemporary hip hop and electronic music. 
Like file sharing, sampling poses a threat to notions of authorship and the private ownership of music, and so the record companies and other established interests in the music industry have subjected it to a number of legal challenges over questions of copyright and fair use (Schumacher 2004). In 1991, the rapper Biz Markie and his record company, Warner Bros., were successfully sued for the use of an unauthorized sample. For many years, the precedent in this ruling would stifle much of the creative energy that had been developing around the practice of sampling in hip hop music. After the decision against Warner Bros., any record company releasing a rap album would be compelled to clear all samples with their publishers, and in most cases the fees were prohibitively expensive. Many rap and hip hop producers began using live instruments and limited the number of samples they used in response to the ruling, as it would no longer be legal to record a densely sampled album like those from the late 1980s. However, a subculture of DJs continued making sample-based hip hop by avoiding samples from popular songs in favor of "digging in the crates" for rare records that might be found in the bulk storage of record stores or at thrift shops, garage sales, or flea markets (Schloss 2004). In 1996, DJ Shadow released his debut album, Entroducing..., that was composed entirely of samples - most of them culled from obscure sources discovered in a massive archive at a record store in Sacramento, pictured on the album's cover with two DJs digging for records - that is widely acclaimed as a pioneering work in the development of sample-based, instrumental hip hop.

The legal conflicts over copyright and the use of digital technologies of reproduction escalated during the initial years of the twenty-first century. Across all forms of popular culture, the evolution of digital technology has enabled the creation of an infinite variety of media collages. Musical "mash-ups" featuring popular songs by well-known artists began to circulate in bootleg form, with some DJs investing creative energies into their mashups and remixes in the way others had done with sampling or turntable scratching. Because of both its musical and its legal significance, the crucial event for the evolution of mash-ups was the 2004 release of Danger Mouse's The Grey Album, which skillfully mixes an a cappella version of Jay-Z's The Black Album with the Beatles' self-titled double record commonly known as The White Album. After The Grey Album was released, EMI, the owner of the publishing rights to the Beatles' music, sent cease-and-desist letters in an attempt to halt distribution and have existing copies of the record destroyed. But EMI's reaction backfired and sparked a counterattack of its own, as more than 150 websites engaged in electronic civil disobedience by making The Grey Album available for a day that organizers called "Grey Tuesday" on which more than 100,000 copies of the album were downloaded illegally.

\section{Conclusions}

From a contemporary perspective, the opposing viewpoints of Adorno and Benjamin about what used to be called "mass culture" appear less like incompatible positions in a debate than complementary illuminations of an enduring and fundamental contradiction between media of reproducibility and the private ownership of capital. In fact, Benjamin suggested that there was a dialectical harmony between their perspectives in a letter that expressed his reactions to Adorno's criticisms of his "Work of Art" essay: "I tried to articulate positive moments as clearly as you managed to articulate negative ones. Consequently, I see strengths in your study at points where mine was weak" (Adorno et al. 2007: 140). The root of the conflict between capitalism and reproducibility is the contradiction originally identified by Marx between the socialization of the productive forces through technological development and the centralization of ownership in the social relations of capital. Indeed, Adorno (2002d: 279) also approximated Benjamin's thinking when writing about the technologies of sonic reproduction independently of their ownership by the culture industry, particularly in an essay on phonographs where he expressed hopes that the creative spirit of music could still be communicated to a wider audience in a recorded medium: "There is no doubt that, as music is removed by the phonograph record from the realm of live production and from the imperative of artistic activity and becomes petrified, it absorbs into itself, in this process of petrification, the very life that would otherwise vanish... Therein may lie the phonograph's record most profound justification, which cannot be impugned by an aesthetic objection to its reification" (also see Levin 1990).

Viewed from an aesthetic standpoint, the Adorno-Benjamin debate is an entrée to a host of issues regarding cultural forms ranging from literature to music, particularly the enduring conflicts over authenticity, modernism, artistic subjectivity, the role of the avant-garde, and the opportunities, or lack thereof, for artists to intervene in wider political struggles. It is little wonder, then, that these two thinkers both occupy an increasingly prominent position in the theoretical braches of the arts and humanities. From a sociological standpoint, however, we can identify another 
side of the intellectual clash between Adorno and Benjamin, one that appears less like a debate between individual theorists than two trajectories of social thought which correspond to diverging aspects of the media and popular culture. If there was a dispute between them, I have suggested, it is because their ideas express a fundamental contradiction between the socializing consequences of productive forces based on reproducibility and the privatizing and centralizing processes stemming from the social relations of the culture industry.

Instead of being perceived as expressions of contradiction, the positions of Adorno and Benjamin have generally served as points of departure for two competing approaches to the study of media and popular culture. Adorno established a style of cultural criticism that centers on political economy, the social relationships of capital and labor, and the conformity of consumer culture, but one which also tends to make condescending assumptions about the duplicity of consumers and the seamless nature of capitalist control over popular culture. Benjamin, on the other hand, has become one of a number of patron saints within interdisciplinary cultural studies, where the activities of audiences and consumers are examined with an eye for the agency exercised in the ability to resist dominant meanings and reclaim cultural commodities to create original meanings. What I hope to have demonstrated by examining the case of popular music and the history of its conflicts between capital and technology is the need to transcend this debate (also see Grossberg 1995), and that the key to establishing a new synthesis in the study of culture and media is to understand these positions as complementary parts of a contradictory whole.

\section{Endnotes}

1. The correspondence between Adorno and Benjamin has now been completely collected and translated published (Adorno and Benjamin 1999), but the focal point of their exchange has been a series of letters that were published in the New Left Review in 1973 and then included in book form accompanying essays by Bloch, Brecht, and Lukács on the topics of modernism, Marxism, and aesthetics (Adorno et al. 2007).

2. The relationship between Adorno and Benjamin was further complicated by the fact that Benjamin was financially dependent on both the Institute for Social Research and Adorno himself for what was, by all accounts, a very precarious existence. The exchange of letters that expressed the intellectual differences between Benjamin and Adorno were written in response to Benjamin's submissions to the Zeitschrift für Sozialforschung, the Institute's journal which helped support Benjamin with a small stipend. At the same time, after moving the Institute from Frankfurt to New York, Adorno and Horkheimer were trying to persuade Benjamin to take refuge with them in the U.S, with events in Europe becoming increasingly dangerous. These circumstances shaped the correspondence between Adorno and Benjamin, and Benjamin's willingness to revise subsequent drafts of his essays in order to appease Adorno and Horkheimer's concerns. In the politicized atmosphere of the late 1960s, as the German New Left had begun to vilify Adorno, some accused the Institute of sanitizing Benjamin's language and editing his essays to make them less Marxist and radical. However, given the political passions attached to Adorno and Benjamin during those times, according to Buck-Morss (1977: 139) "this interpretation is misleadingly one-sided" (also see Jay 1973; Wiggershaus 1995). It is essential to clarify that my approach does not subscribe to technological determinism or the "analytic Marxism" of G.A. Cohen (2001), who maintains that Marx assigned causal primacy to the productive forces. As David Harvey (2006: 98) put it, "Of all the misinterpretations of Marx's thought, perhaps the most bizarre is that which makes a technological determinist of him." In the first place, although Marx did believe that technology is essential for disclosing the development of productive forces, he did not equate the two. More important, productive forces and social relations are in reality inseparable parts of a totality, whose motor force is never simply a one-sided determination but is instead a dialectical process of contradiction and conflict.

The usual English translation of this essay, "The Work of Art in the Age of Mechanical Reproduction," neglects Benjamin's addition of the suffix -barkeit (-ability, as in capability) to the final word, and as Samuel Weber (2008) has shown, Benjamin's use of barkeit was a key element in his thinking and writing, for it attached a sense of potential and process to verbs that otherwise indicated a completed action. As the essay has gained influence, its four different versions have been compared in light of the revisions made for its eventual publication, and the second version has generally been considered the most complete while also the most daring because it maintains direct references to Marx, fascism, and socialism. Thus, in the most recent collection of Benjamin's texts on media, it is the second version which is reprinted, and that is the version I will refer to in this paper. However, the different variations and slightly modified translations are still similar enough that it should not cause difficulties for those only familiar with the version in Illuminations, Benjamin's most well-known and frequently reproduced collection of essays. 


\section{References}

Adorno, Theodor W. 1991. The Culture Industry, edited by James M. Bernstein. New York: Routledge.

-.---. 2002a. "On the Fetish Character in Music and the Regression of Listening." Pp. 288-317 in Essays on Music, edited by Richard Leppert. Berkeley: University of California Press.

-----. 2002b.“On the Social Situation in Music.” Pp. 391-436 in Essays on Music, edited by Richard Leppert. Berkeley: University of California Press.

-----. 2002c. “On Popular Music." Pp. 437-469 in Essays on Music, edited by Richard Leppert. Berkeley: University of California Press. Berkeley: University of California Press.

-..-.. 2002d. "The Form of the Phonograph Record." Pp. 277-282 in Essays on Music, edited by Richard Leppert. Berkeley: University of California Press. Berkeley: University of California Press.

Adorno, Theodor W. and Walter Benjamin. 1999. The Complete Correspondence, edited by Henri Lonitz. Cambridge, MA: Harvard University Press.

Adorno, Theodor W., Walter Benjamin, Ernst Bloch, Bertolt Brecht, and Georg Lukács. 2007. Aesthetics and Politics. New York: Verso.

Agger, Ben. 2007. Public Sociology: From Social Facts to Literary Acts (second ed.). Lanham, MD: Rowman \& Littlefield.

Albini, Steve. 1997. “The Problem with Music.” Pp. 164-176 in Commodify Your Dissent: Salvos from The Baffler, edited by Thomas Frank and Matt Weiland. New York: W.W. Norton \& Company.

Arato, Andrew and Eike Gebhardt.. 1982. "Esthetic Theory and Cultural Criticism." Pp. 185-224 in The Essential Frankfurt School Reader, edited by Andrew Arato and Eike Gebhardt. New York: Continuum.

Azerrad, Michael. 2002. Our Band Could Be Your Life: Scenes from the American Indie Underground, 1981-91. New York: Little, Brown.

Bagdikian, Ben. 2004. The New Media Monopoly. Boston: Beacon Press.

Baudrillard, Jean. 1994. Simulacra and Simulation. Ann Arbor: University of Michigan Press.

Benjamin, Andrew (ed). 2005. Walter Benjamin and Art. New York: Continuum.

Benjamin, Walter. 1968. “'The Storyteller.” Pp. 217-251 in Illuminations, edited by Hannah Arendt. New York: Schoken.

1978. “The Author as Producer." Pp. 220-238 in Reflections, edited by Peter Demetz. New York: Schoken.
-----. 2006. The Writer of Modern Life: Essays on Charles Baudelaire, edited by Michael W. Jennings. Cambridge, MA: Belknap/Harvard.

----. 2008. "The Work of Art in the Age of Its Technological Reproducibility." Pp. 19-55 in The Work of Art in the Age of Its Technological Reproducibility, and Other Writings on Media, edited by Michael W. Jennings, Brigid Doherty, and Thomas Y. Levin. Cambridge, MA: Belknap/Harvard.

Bourdieu, Pierre. 1993. The Field of Cultural Production: Essays on Art and Literature. New York: Columbia University Press.

1996. The Rules of Art: Genesis and Structure of the Literary Field. Stanford: Stanford University Press.

Bronner, Stephen E. 2002. Of Critical Theory and Its Theorists. New York: Routledge.

Buck-Morss, Susan. 1977. The Origin of Negative Dialectics: Theodor W. Adorno, Walter Benjamin, and the Frankfurt Institute. New York: The Free Press.

Chang, Jeff. 2005. Can's Stop, Won't Stop: A History of the Hip-Hop Generation. New York: Picador.

Chapple, Steve and Reebee Garofalo. 1977. Rock 'N' Roll Is Here to Pay: The History and Politics of the Music Industry. Chicago: Nelson-Hill.

Cohen, G.A. 2001. Karl Marx's Theory of History: A Defense. Princeton, N.J.: Princeton University Press.

Croteau, David and William Hoynes. 2006. The Business of Media: Corporate Media and the Public Interest. Thousand Oaks, CA: Pine Forge Press.

Debord, Guy. 1983. Society of the Spectacle. Detroit: Black \& Red.

DeNora, Tia. 2003. After Adorno: Rethinking Music Sociology. New York: Cambridge University Press.

Dowd, Timothy J. 2004. "Concentration and Diversity Revisited: Production Logics and the U.S. Mainstream Recording Market, 1940-1990." Social Forces 82: 1411-1455.

Ferris, David S. (ed). 2004.The Cambridge Companion to Walter Benjamin. New York: Cambridge University Press.

Forman, Murray and Mark Anthony Neal (eds.). 2004. That's the Joint! The Hip Hop Studies Reader. New York: Routledge.

Frith, Simon. 1981. Sound Effects: Youth, Leisure, and the Politics of Rock 'N' Roll. New York: Pantheon Books.

Fuchs, Christian. 2011. "A Contribution to the Critique of the Political Economy of Google." Fast Capitalism8: 1. 
Gendron, Bernard. 1986. "Theodor Adorno Meets the Cadillacs." Pp. 18-36 in Studies in Entertainment, edited by Tania Modleski. Bloomington: University of Indiana Press.

Gibson, Nigel and Andrew Rubin (eds). 2002. Adorno: A Critical Reader. Malden, MA: Blackwell.

Gillett, Charlie. 1983. The Sound of the City: The Rise of Rock and Roll. New York: Pantheon.

Goodwin, Andrew. 1988. "Sample and Hold: Pop Music in the Digital Age of Reproduction.” Critical Quarterly 30: 34-49.

Gracyk, Theodore. 1992. "Adorno, Jazz, and the Aesthetics of Popular Music.” The Musical Quarterly 76: 526-42.

Grossberg, Lawrence. 1986. "Is There Rock After Punk?” Critical Studies in Mass Communication 3: 50-74.

-----. 1995. "Cultural Studies vs. Political Economy: Is Anybody Else Bored with This Debate?" Critical Studies in Mass Communication 12: 72-81.

Gumbrecht, Hans. and Michael Marrinan (eds). 2003. Mapping Benjamin: The Work of Art in the Digital Age. Stanford, CA: Stanford University Press.

Hansen, Miriam Bratu. 1993. "Of Mice and Ducks: Benjamin and Adorno on Disney.” South Atlantic Quarterly 92: 27-61.

------. 2011. Cinema and Experience: Siegfried Kracauer, Walter Benjamin, and Theodor W. Adorno. Berkeley: University of California Press.

Hanssen, Beatrice and Andrew Benjamin (eds.). 2002. Walter Benjamin and Romanticism. New York: Continuum.

Harvey, David. 2006. The Limits to Capital. New York: Verso.

Hebdige, Dick. 1979. Subculture: The Meaning of Style. New York: Routledge.

Held, David. 1980. Introduction to Critical Theory: Horkheimer to Habermas. Berkeley: University of California Press.

Hesmondhalgh, David. 1997. "Post-Punk's attempt to democratise the music industry: the success and failure of Rough Trade." Popular Music 16: 255-274.

Horkheimer, Max. and Theodore W. Adorno. 2002. "The Culture Industry: Enlightenment as Mass Deception.” Pp. 94-136 in Dialectic of Enlightenment. Stanford, CA: Stanford University Press.

Huhn, Tom (ed). 2004. The Cambridge Companion to Adorno. New York: Cambridge University Press.

Huyssen, Andreas. 1983. "Adorno in Reverse: From Hollywood to Richard Wagner." New German Critique 29: 8-38.

Jameson, Fredric. 1990. Late Maxism: Adorno, or the Persistence of the Dialectic. New York: Verso.
Jay, Martin. 1973. The Dialectical Imagination: A History of the Frankfurt School and the Institute of Social Research, 19231950. Boston: Little, Brown.

1984. Adorno. Cambridge, MA: Harvard University Press.

Kellner, Douglas. 1989. Critical Theory, Marxism, and Modernity. Baltimore: Johns Hopkins University Press.

Klinenberg, Eric. 2007. Fighting for Air: The Battle to Control America's Media. New York: Metropolitan Books.

Knopper, Stephen. 2009. Appetite for Self-Destruction: The Spectacular Crash of the Record Industry in the Digital Age. New York: Free Press.

Kot, Greg. 2009. Ripped: How the Wired Generation Revolutionized Music. New York: Scribner.

Kusek, David and Gerd Leonhard. 2005. The Future of Music: Manifesto for the Digital Revolution. Boston: Berklee Press.

Levin, Thomas Y. 1990. "For the Record: Adorno on Music in the Age of Its Technological Reproducibility." October 55: 23-47.

Lopes, Paul. 1992. "Innovation and Diversity in the Popular Music Industry, 1969 to 1990.” American Sociological Review 57: 56-71.

Lunn, Eugene. 1982. Marxism and Modernism: An Historical Study of Lukács, Brecht, Benjamin, and Adorno. Berkeley: University of California Press.

Marcus, Greil. 1989. Lipstick Traces: A Secret History of the Twentieth Century. Cambridge: Harvard University Press.

Marx, Karl. 1977. Capital: A Critique of Political Economy, volume I. New York: Vintage Books.

-.---. 1978. "Preface" to A Contribution to the Critique of Political Economy. Pp. 3-6 in The Marx-Engels Reader, edited Robert C. Tucker. New York: Vintage.

McChesney, Robert W. 1999. Rich Media, Poor Democracy: Communication Politics in Dubious Times. Urbana: University of Illinois Press.

Middleton, Richard. 2006. Voicing the Popular: On the Subjects of Popular Music. New York: Routledge.

Moore, Ryan. 2007. "Friends Don't Let Friends Listen to Corporate Rock: Punk as a Field of Cultural Production.” Journal of Contemporary Ethnography 36: 438-474.

Negus, Keith. 1996. Popular Music in Theory: An Introduction. Middletown, CT: Wesleyan University Press.

Paddison, Max. 1982. "The Critique Criticized: Adorno and Popular Music.” Popular Music 2: 201-218.

Park, David J. 2007. Conglomerate Rock: The Music Industry's Quest to Divide Music and Conquer Wallets. New York: Lexington Books. 
Peterson, Richard. 1990. "Why 1955?” Popular Music 9: 97-116.

Peterson, Richard and David Berger. 1975. "Cycles in Symbol Production: The Case of Popular Music." American Sociological Review 40: 158-173.

Potter, Russell A. 1995. Spectacular Vernaculars: Hip-Hop and the Politics of Postmodernism. Albany: SUNY Press.

Rose, Tricia. 1994. Black Noise: Rap Music and Black Culture in Contemporary America. Hanover: University Press of New Hampshire.

Rosen, Michael. 2004. "Benjamin, Adorno, and the Decline of Aura." Pp. 40-56 in The Cambridge Companion to Critical Theory, edited by Fred L. Rush. New York: Cambridge University Press.

Ross, Andrew. 1989. No Respect: Intellectuals and Popular Culture. New York: Routledge.

Savage, Jon. 1993. England's Dreaming: Anarchy, Sex Pistols, Punk Rock, and Beyond. New York: St. Martin's.

Schloss, Joseph. 2004. Making Beats: The Art of Sample-Based Hip Hop. Middletown, CT: Wesleyan University Press.

Schumacher, Thomas G. 2004. “'This Is a Sampling Sport': Digital Sampling, Rap Music, and the Law in Cultural Production." Pp. 443-458 in That's the Joint! The Hip Hop Studies Reader, edited by Murray Forman and Mark Anthony Neal. New York: Routledge.
Sheff, David and Rob Tannenbaum. 2007. "Rip.Burn.Die." Pp. 337-350 in The Rock History Reader, edited by Theo Cateforis. New York: Routledge.

Subotnik, Rose Rosengard. 1996. Deconstructive Variations: Music and Reason in Western Society. Minneapolis: University of Minnesota Press.

Thompson, Stacy. 2004. Punk Productions: Unfinished Business. Albany: SUNY Press.

Walker, Rob. 2008. “Girl Talk.” New York Times, July 20.

Weber, Samuel. 2008. Benjamin's -abilities. Cambridge, MA: Harvard University Press.

Wiggershaus, Rolf. 1994. The Frankfurt School: Its Histories, Theories, and Political Significance. Cambridge: MIT Press.

Wilcock, Evelyn. 1996. “Adorno Jazz and Racism: 'Uber Jazz' and the 1934-1937 British Jazz Debate." Telos 107 (Spring): 63-80.

Witkin, Robert W. 2000. "Why Did Adorno 'Hate' Jazz?" Sociological Theory 18: 145-70.

-----. 2003. Adorno on Popular Culture. New York: Routledge. Wolin, Richard. 1982. Walter Benjamin: An Aesthetic of Redemption. New York: Columbia University Press. 